\title{
Efficient genomic DNA extraction protocol from medicinal rich Passiflora foetida containing high level of polysaccharide and polyphenol
}

\author{
Bipin Deochand Lade*, Anita Surendra Patil and Hariprassad Madhukarrao Paikrao
}

\begin{abstract}
In Present work, the main objective is to develop less time consuming protocol for genomic DNA isolation from leaves of Passiflora foetida. Optimized protocol is cost effective, as it avoided use of expensive liquid nitrogen. The important parameters of CTAB buffer composition such as Polyvinylpyrrolidone PVP40000 (without PVP, 1\%, 2\%, $3.5 \%, 4.0 \%, 4.5 \%, 5.0 \%), \mathrm{CTAB}(\mathrm{W}, 1 \%, 2 \%, 3 \%, 4 \%, 5 \%)$, water bath temperature $\left(30^{\circ} \mathrm{C}\right.$ to $\left.70^{\circ} \mathrm{C}\right)$ and duration on water bath for half hr and one and half hr has been optimized. CTAB (2\%), PVP (1\%), water bath temperature (70\%), duration on water bath (1 hr) has efficiently yielded DNA quality of 200-1782 $\mu \mathrm{g} / 0.5 \mathrm{gm}$ from leaf, stem, root, tendril and flower. However, $168 \mu \mathrm{g}-1782 \mu \mathrm{g}$ of DNA has been obtained from $0.5 \mathrm{~g}$ of leaf of Passiflora foetida. Polyphenol contamination has been overcome using $5 \mathrm{M} \mathrm{NaCl}$ and PVP. Acetate has been used for obtaining double-stranded DNA in stabilized form. Current DNA extraction protocol takes maximum of four hours for completion, which is many time savings. RAPD-PCR reaction parameters such as DNA concentration (100ng), Primer concentration (2 $\mu \mathrm{M})$, Dream Taq polymerase $(2 \mathrm{U})$, annealing temperature $\left(29^{\circ} \mathrm{C}\right)$ and number of cycles for amplification of DNA has been optimized. Primer fragment Akansha 7 shows high polymorphism of 7 fragments ranges from 200bp - $2500 \mathrm{bp}$. Current optimized protocol of DNA isolation is specifically for Passiflora foetida, which can be used for downstream molecular techniques.
\end{abstract}

Keywords: DNA extraction; Passiflora foetida; PCR- RAPD; Phylogenetic analysis

\section{Introduction}

The Genus Passiflora native to Brazil consisted of more than 600 species distributed in tropical and sub tropical part of the world, including India, Thailand, Myanmar, Indonesia, Singapore (Souza et al., 2008). In India, Passiflora is well known for unique, diversified eye catching flower, extremely used for gardening and decoration purpose. This rare feature has been attraction for extraction of genomic DNA from flower and leaves. P. foetida is prominent for pharmacological products that are highly acceptable in Brazil, India, America, Vietnam and European nations Ulubelen et al., (1982).

Passiflora foetida contain large secondary metabolites such as phenols, alkaloids, polyphenol and polysaccharide (Barra et al., 2012; Dhawan et al., 2002; Dhawan K et al., 2004). During DNA extraction, these compounds

\footnotetext{
* Correspondence: dbipinlade@gmail.com

Department of Biotechnology, Sant Gadge Baba Amravati University, Amravati 444602 (M.S), India
}

inhibit enzymes such as ligase, polymerase and nucleases (Barra et al. 2012) which produced negative results of restriction digestion, PCR, RAPD and cloning experiments (Howland et al., 1991; Katterman and Shattuck, 1983). Thus, in current paper such situations have been overcome by development of protocol, which isolates genomic DNA from P. foetida. Protocol presented here neglects the use of liquid nitrogen, which may not be available in fewer laboratories of underdeveloped and the progressing countries. All reagent and chemical used for optimization of DNA extraction has been manipulated in different combination for obtaining pure DNA from the leave sample (Suman et al., 1999; Khanuja et al., 1999; Doyle and Doyle, 1990; Doyle et al., 1987; Dellaporta et al., 1983). Same protocol has efficiently used for extraction of DNA from flower, tendrils, and stem. The research by (Crochemore et al. 2003; Fajardo et al. 1998) has concluded several species of the genus Passiflora using RAPD markers. 
Table 1 Representation of the primer used with their respective sequences and PCR-RAPD generated analysis of polymorphic fragments

\begin{tabular}{llll}
\hline Primer fragment & Sequence $\left(\mathbf{5}^{\prime} \boldsymbol{\rightarrow} \mathbf{3}^{\prime}\right)$ & References & Number of amplified fragments \\
\hline Akansha 1 & OPA04-AATCGGGCTG & Crochemore M. L et al., 2003 & 5 \\
Akansha 2 & OPB08-GTCCACACGG & Crochemore M. L et al., 2003 & 3 \\
Akansha 3 & OPB18-CCACAGCAGT & Crochemore M. L et al., 2003 & 6 \\
Akansha 4 & OPB19-ACCCCCGAAG & Crochemore M. L et al., 2003 & 7 \\
Akansha 5 & OPB20-GGACCCTTAC & Crochemore M. L et al., 2003 & 3 \\
Akansha 6 & 1-CCTGGGCTCC & Aukar et al., 2003 & 3 \\
Akansha 7 & 5-CCTGGGTCC & Aukar et al., 2003 & 9 \\
Akansha 8 & 53-CTCCCTGAGC & Aukar et al., 2003 & 3 \\
Akansha 9 & 54-GTCCCAGAGC & Aukar et al., 2003 & 6 \\
Akansha10 & CGGGAGACCC & Chalmers et al., 1992 & 6
\end{tabular}

\section{Materials and methods}

\section{Reagents and chemicals}

The reagents and chemical that are used for preparation of $100 \mathrm{ml}$ CTAB buffer are CTAB (Hexadecyltrimethyl- ammonium bromide) $2.0 \mathrm{gm}, 1 \mathrm{M}$ Tris $\mathrm{Cl}$ (pH 8.0) $10 \mathrm{ml}, 0.5 \mathrm{M}$ EDTA (pH 8.0) $4 \mathrm{ml}, 5.0 \mathrm{M} \mathrm{NaCl}$ $28 \mathrm{ml}$ and $\mathrm{H}_{2} \mathrm{O} 40 \mathrm{ml}$, PVP 40 (polyvinyl pyrrolidine) $1 \mathrm{gm}$, adjust all to $\mathrm{pH} 5$ with HCL and make volume up to $100 \mathrm{ml}$ by double distilled water and other chemicals are as fallows $\mathrm{NaOH} 10 \mathrm{M}$ (pH adjustment of buffer), 3.5 $\mathrm{M}$ sodium acetate $(\mathrm{pH} 5.3)$, pure cold $\left(-20^{\circ} \mathrm{C}\right)$ isopropanol, chloroform: isoamyl alcohol $(24: 1 \mathrm{v} / \mathrm{v}), 70 \%$ ethanol, absolute ethanol, Enzyme: Dream Taq DNA polymerase (Fermentas Inc), Rnase A (Fermentas Inc), Protinase K (Fermentas Inc), Buffer: 10x Dream Taq Green buffer (Fermentas Inc), Nucleotides: dNTPs (G, A, T, C) $2 \mathrm{mM}$ and RAPD primers, TAE buffer, agarose gel and ethidium bromide (Crochemore et al. 2003; Williams et al., 1990).

\section{Plant material}

Passiflora foetida studied in this research were originated from India. Initially, seeds were gowned at university department garden Amravati University, Amravati (M.S) India. The young leaf samples of 40-50 $\mathrm{mg}$ from plants were harvested and used for optimization of the DNA.

\section{DNA extraction protocol}

DNA extraction from Passiflora foetida was performed by an improved CTAB (cetyltrimethylammonium bromide detergent) method without using liquid nitrogen. DNA extraction protocol steps are as fallows.

1. Weight 0.5 gm of leaf sample of Passiflora foetida.

2. Grind leaf sample in mortal with the pestle in $1 \mathrm{ml}$ CTAB buffer (liquid nitrogen not used).

3. Transfers to $2 \mathrm{ml}$ eppendorf tubes add RNase A $20 \mathrm{ug} / \mathrm{ml}$ or (1 ul from 10 millligram/ml) mix well and incubate at $37^{\circ} \mathrm{C}$ for $15 \mathrm{~min}$.

4. Add $10 \mathrm{ul}$ proteinase $\mathrm{k}(1 \mathrm{mg} / \mathrm{ml})$ and incubate in water bath at $65-70^{\circ} \mathrm{C}$ for $1 \mathrm{hr}$ (Mix in between).

5. Allow to attain room temperature, add equal volume of chloroform isoamyl alcohol 24:1 i.e. $1 \mathrm{ml}$ (equal volume to CTAB buffer).

6. Centrifuge at $12,000 \mathrm{~g}$ for 15 minutes, take supernatant carefully in fresh $2 \mathrm{ml}$ eppendorf tube \& discard pellet. (700 $\mu \mathrm{l}$ of the supernatant taken in the fresh $2 \mathrm{ml}$ tube).

7. Add half volume of $5 \mathrm{M} \mathrm{NaCl}$ i.e. $350 \mu \mathrm{l}$ (Mix well) keep it on ice bath for 15 min.

8. Add sodium acetate $1 / 10$ volume of the supernatant i.e. $70 \mu \mathrm{l}$ and add ice cold isopropyl alcohol $(2 / 3)$ of the supernatant i.e. $500 \mu$ l. (Invert slowly thrice to precipitate DNA, small fiber of DNA sitting down will be observed).

Table 2 Optimization of CTAB DNA extraction buffer components for Passiflora foetida

\begin{tabular}{ccccc}
\hline Sr no & Parameters & Tested range & Optimum conditions & Inferences \\
\hline 1 & CTAB & W, $1 \%, 2 \%, 3 \%, 4 \%, 5 \%$ & $2 \%$, & Disrupts cell membranes \\
2 & PVP & W, $1 \%, 2 \%, 3 \%, 3.5 \%, 4 \%, 4.5 \%, 5 \%$ & $1 \%$, & Effects DNA quality \\
3 & Water bath temperature & $30^{\circ} \mathrm{C}, 50^{\circ} \mathrm{C}, 60^{\circ} \mathrm{C}, 65^{\circ} \mathrm{C}, 70^{\circ} \mathrm{C}$ & 1 hrs & Less temperature increase contamination chances \\
4 & Duration on water bath & Half hrs, 1 hrs & Less duration effects DNA purity \\
\hline
\end{tabular}

Note: CTAB: (CTAB- catyltrimethylammonian bromide detergent) PVP:1\%, W: without. 
9. Invert eppendroff tubes thrice and keep it $-20^{\circ} \mathrm{C}$ for half hr.

10. Centrifuge at $11,000 \mathrm{~g}$ for 5 minutes, discard supernatant and take pellet.
11. Tubes containing pellet are allowed to air dry for 5-10 minutes. Invert tubes on tissue paper to complete run off supernatant.
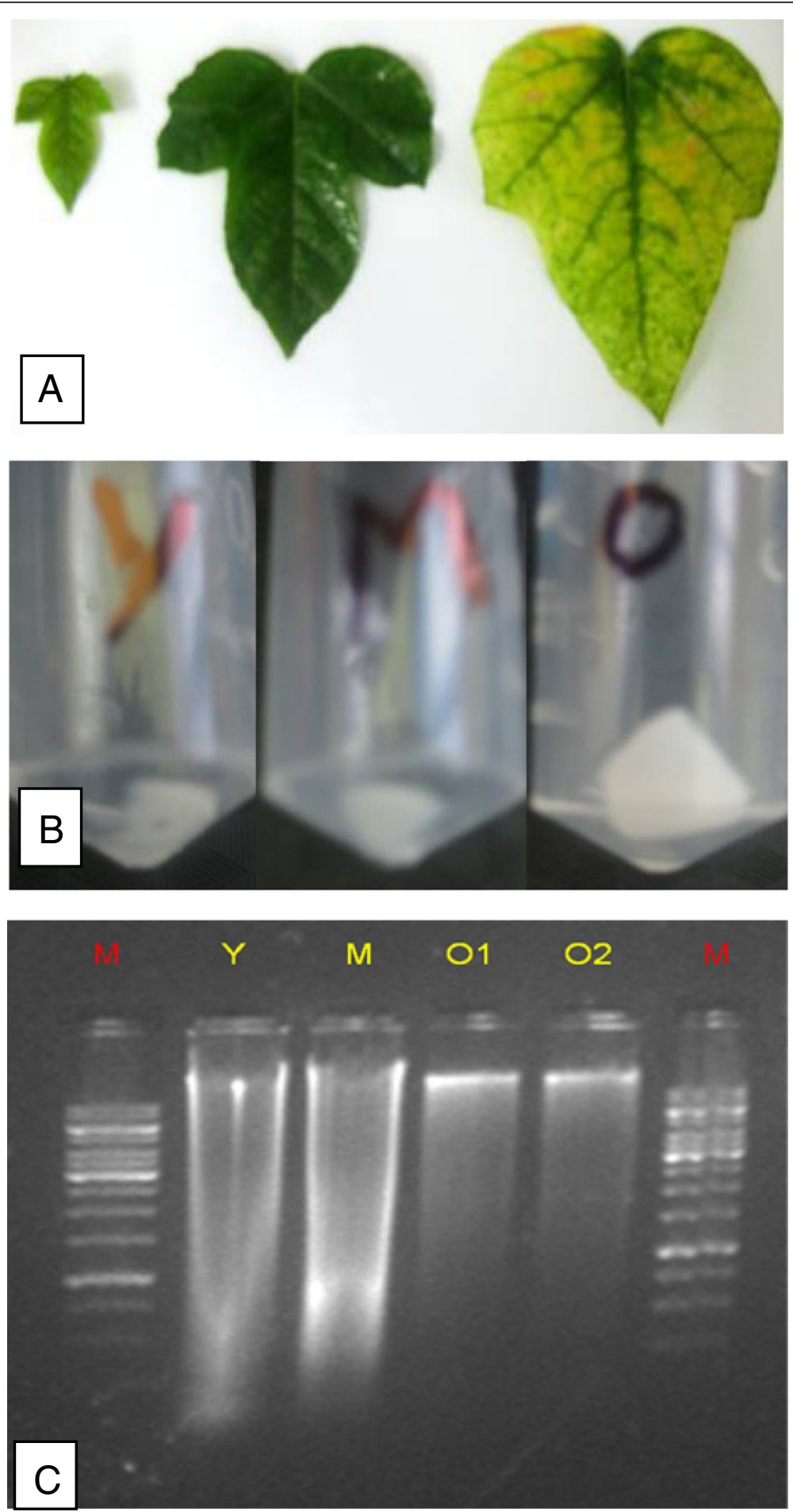

Figure 1 DNA Isolated from leaf sample of Passiflora foetida loaded in 1.2\% agarose gel, picture taken under gel documented system (Bio Rad). A: leaf sample of young, mature, old leaf of Passiflora foetida. B: white color jelly like DNA in eppendroff tube after extraction process. C: DNA sample extracted from young $(\mathrm{Y})$, mature $(\mathrm{M})$ and old $(\mathrm{O})$ leaf sample of Passiflora foetida. 


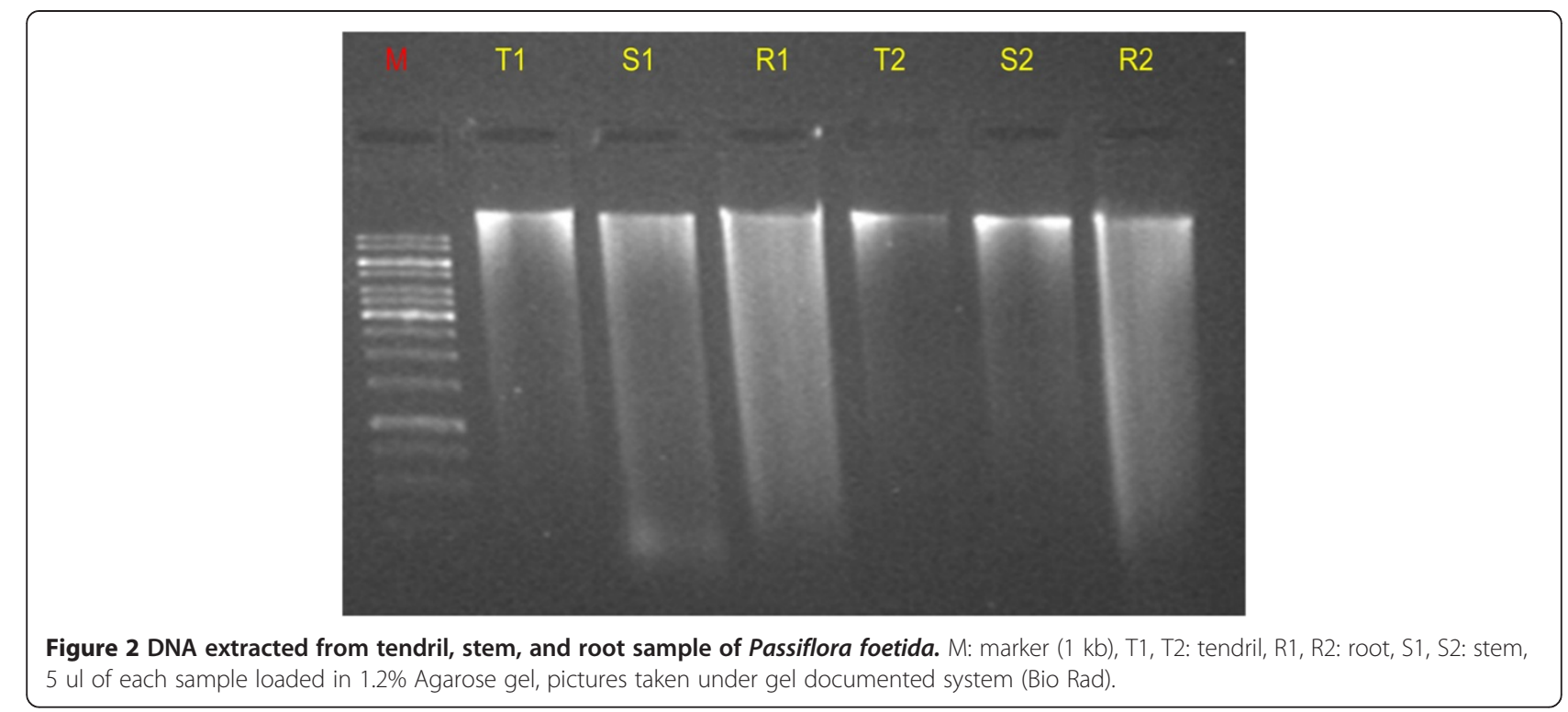

12. Wash DNA pellet with $500 \mu \mathrm{l}$ of $70 \%$ ethanol, centrifuge 11,000 g for 5 minutes (so that salt will dissolve, and purity of DNA will increase).

13. Discard 70\% alcohol from tubes. Allow tubes containing pellet to air dry for 15 min on tissue paper in inverted position. Dissolved pellet in $100 \mathrm{ul}$ NFW and stored in $-20^{\circ} \mathrm{C}$ for further downstream procedures.

\section{Results and discussion}

The primers sequences that are used in current study for RAPD PCR are given in Table 1. An optimization of
CTAB DNA extraction buffer components such as Tris, EDTA, $\mathrm{NaCl}, \mathrm{PVP}$ and CTAB (Rogers et al., 1985) are shown in Table 2. Tris interacts with the lipopolysaccharides presents on the outer membrane to denature plasma membrane and help in disruption on cell membrane. EDTA is a chelating agent it chelate $\mathrm{Mg}^{++}$ions necessary for DNase activity. Thus, DNA remains protected from DNase enzyme, which requires $\mathrm{Mg}^{++}$ions for its activity. DNA pellet sometime shows yellow or brown to greenish color indicates contamination of polysaccharides and polyphenol. In general, polysaccharides are very difficult to remove that interfere with a DNA
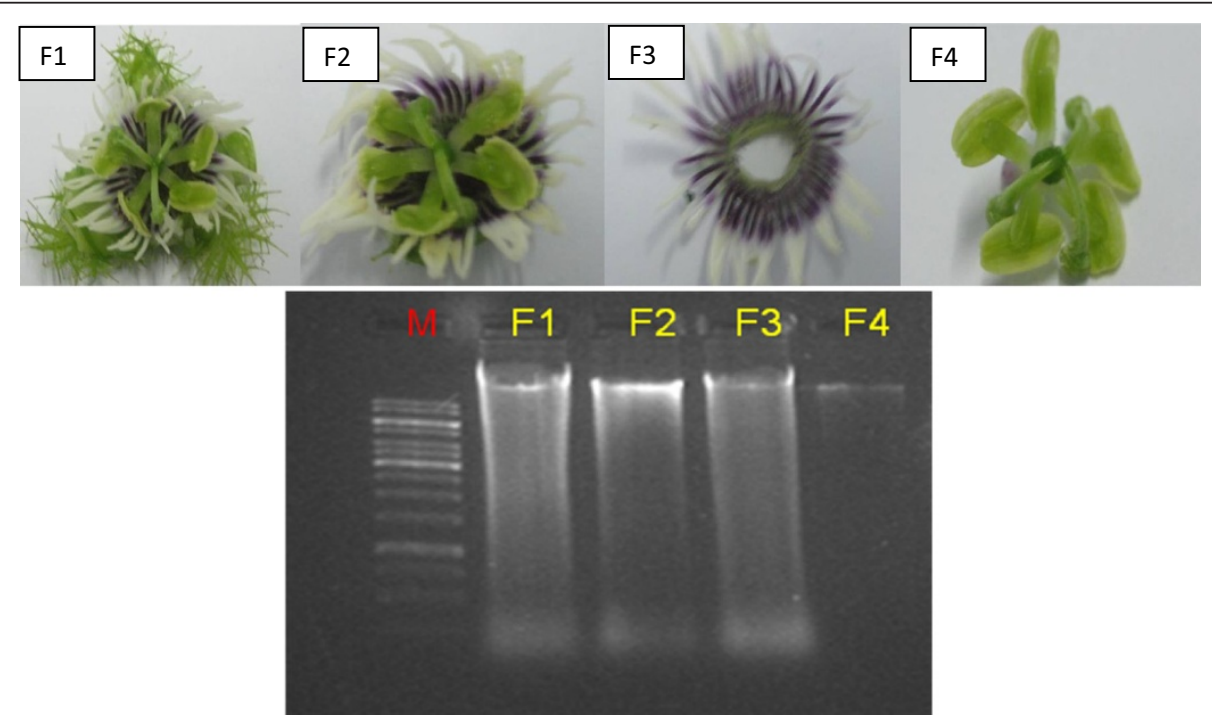

Figure 3 DNA extracted from various parts of flower of Passiflora foetida (M: marker 1 kb. F1: whole flower, F2: without sepals, F3: without reproductive system, F4: reproductive system only). 5 ul of each sample loaded in 1.2\% Agarose gel, picture taken under gel documented system (Bio Rad). 
Table 3 Optimization of the RAPD-PCR reaction parameters for amplification of genomic DNA of Passiflora foetida

\begin{tabular}{lllll}
\hline Sr no & PCR parameters & Tested range & $\begin{array}{l}\text { Optimum } \\
\text { conditions }\end{array}$ & Inferences \\
\hline 1 & DNA concentration $(\mathrm{ng})$ & $50,75,100,150,200$ & $100 \mathrm{ng}$ & $\begin{array}{l}\text { Less amplification with lower concentration and } \\
\text { smear formation at higher concentration }\end{array}$ \\
2 & Primer concentration $(\mu \mathrm{M})$ & $1,1.5,2,2.5,3,3.5,4,4.5,5.2 \mu \mathrm{M}$ & $\begin{array}{l}\text { Minimum amount produces sufficient amplification } \\
\text { Sufficient for proper amplification. }\end{array}$ \\
3 & Dream Taq polymerase (units) & $2 \mathrm{U}, 5 \mathrm{U}$ & $2 \mathrm{U}$ & $\begin{array}{l}\text { Lower annealing temperatures show proper annealing } \\
\text { and amplification }\end{array}$ \\
5 & Annealing temperature $\left({ }^{\circ} \mathrm{C}\right)$ & $25,27,29,30,35,40,44$ & $29^{\circ} \mathrm{C}$ & Higher/lower cycles (from optimum) effects the amplification \\
\hline
\end{tabular}

isolation process (Kit and Chandran, 2010: Clark, 1997). In this experiment $5 \mathrm{M} \mathrm{NaCl}$ treatments was given to DNA in aqueous phase prior to DNA precipitation, which helps to remove polysaccharides (Kit and Chandran, 2010: Clark, 1997). Similarly, $5 \mathrm{M} \mathrm{NaCl}$ was used by (Kit and Chandran, 2010; Khanuja et al., 1999) in their protocol. Polyphenol is productively removed by using PVP, which forms a complex hydrogen bonding with polyphenol and efficiently separate it from DNA (Kit and Chandran, 2010: Doyle and Doyle, 1990). In CTAB buffer, various grades of PVP \% such as without PVP, 1\%, 2\%, 3\%, 3.5\%, 4\%, 4.5\%, $5 \%$ as mention by (Khanuja et al., 1999) were tried. All compositions of CTAB buffer kept constant with varying PVP \%. It was found that the DNA purity and concentration decrease as the PVP concentration increases. 1\% PVP yields approximate $0998.7 \mu \mathrm{g}$ from $0.5 \mathrm{gm}$ of leaf sample, 2.06 and $\mathrm{A}_{260 / 230}=1.99,3.5 \% \mathrm{PVP}$ produces 210.9 $449.5 \mu \mathrm{g} \mathrm{A}_{60 / 280}=1.56 \pm 13$ and $\mathrm{A}_{260 / 230}=0.75 \pm 10,4.0 \%$ PVP yields $A_{260 / 280}=1.50 \pm 6$ and $A_{260 / 230}=0.67 \pm 5,4.5 \%$ PVP yields 276-282 $\mu \mathrm{g} \mathrm{A}_{260 / 280}=1.68 \pm 3$ and $\mathrm{A}_{260 / 230}=$ $0.82 \pm 5,5.0 \%$ PVP yields $A_{260 / 280}=1.70$ and $A_{260 / 230}=$
0.81. Thus, $1 \%$ PVP has found to produce good DNA quality (Murray et al., 1980).

Further, grinded leaf sample in CTAB buffer was incubated on water bath and tested for temperature $55^{\circ} \mathrm{C}$ to $70^{\circ} \mathrm{C}$. It was observed that when grinded leaf in extraction buffer kept for $65^{\circ} \mathrm{C}$ or less temperature, incomplete denaturation of proteins may occur which produces contamination in further extraction steps. The ground sample in CTAB buffer tested for optimization of incubation time. It was tested for minimum $25 \mathrm{~min}$ to $60 \mathrm{~min}$. Thus $1 \%$ PVP and $70^{\circ} \mathrm{C}$ water bath for 1 hrs has been optimized to produce best yield of DNA. It produces $168.2 \mu \mathrm{g} / \mathrm{ml}$ to $1782.5 \mu \mathrm{g} / \mathrm{ml}$ from $0.5 \mathrm{~g}$ of leaf samples $\mathrm{A}_{260 / 280}=1.80 \pm$ 22 and $\mathrm{A}_{260 / 230}=1.75 \pm 20$. The current protocol produces good quality and quantity of DNA when compared with another DNA isolation protocol. Krizman DNA extraction method produces $411 \mu \mathrm{g} / \mathrm{g}$ of leaf tissue (Abu-Romman, S. 2011).

Denaturation and removal of protein are very important to avoid its interference with DNA. Thus chloroform: isoamylalcohol (24:1) was used for denaturing proteins from

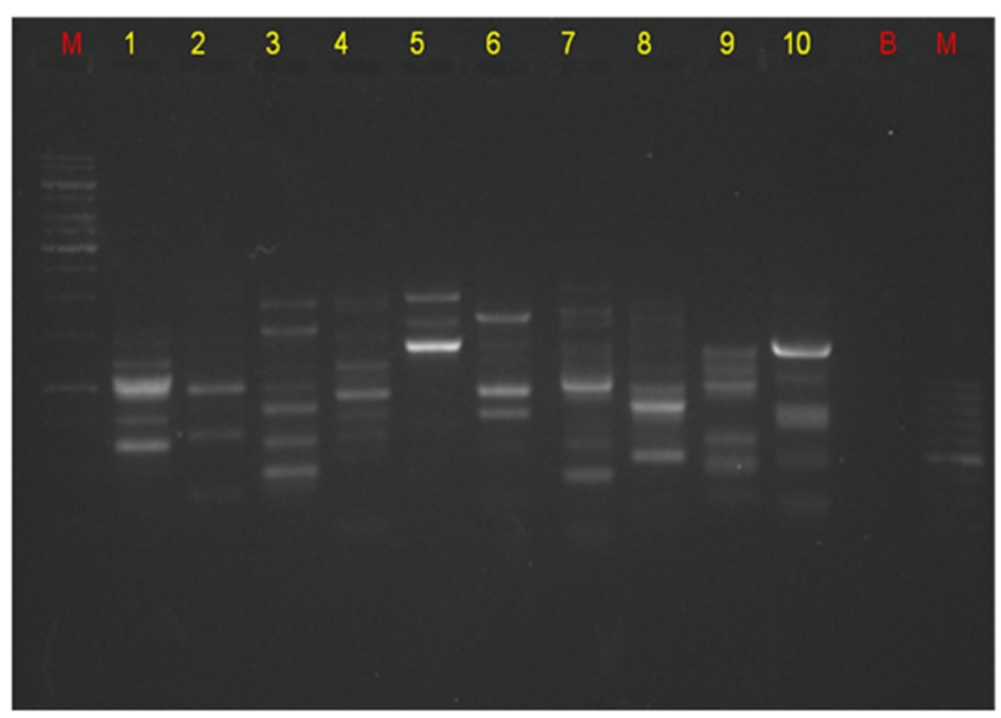

Figure 4 Optimized Akansha primer 1,2,3,4,5,6,7,8,9,10, M: 1 kb ladder (right) and 100 bp (left) ladder, B: blank, PCR- RAPD Analysis - of Passiflora foetida. Loaded in 1.2\% agarose gel, picture taken under gel documented system (Bio Rad). 
DNA allowing only DNA in the supernatant after centrifugation step (Puchooa, D. 2004). At fewer moments supernatant has some greenish to yellowish color, which can be eliminated by repeating chloroform isoamylalcohole step. DNA in the supernatant was treated with half vol of $5 \mathrm{M} \mathrm{NaCl}$ (Kit and Chandran, 2010; Khanuja et al., 1999) which productively helps in removing polyphenol and polysaccharides. However, (Abu-Romman, S. 2011) has impressively used activated charcoal and PVP directly in the CTAB extraction buffer which efficiently removes polysaccharides and polyphenol. DNA is precipitated by using isopropanol and sodium acetate. In presence of water sodium acetate donates $\mathrm{Na}^{++}$to DNA strand and interacts with -ve charges of the phosphate group of DNA to form complex to reduce repulsion of both strands (DNA strand -ve charge) and help to obtain DNA in an intact form. Finally, pellet of DNA washed with 70\% ethanol to remove salts, a white color jelly like DNA was observed at bottom of eppendorf tube.

Thus, our optimized protocol for DNA extraction from $0.5 \mathrm{~g}$ of leaf sample yield's DNA of $168 \mu \mathrm{g}-1782 \mu \mathrm{g} / \mathrm{ml}$. Figure 1 shows isolated DNA from leaf sample (young, mature, old) of Passiflora foetida that were loaded in $1 \%$ agarose gel and picture taken with gel documentation system. Same protocol has been used successfully for isolation of DNA from stem, root, flower and tendril. Figure 2 shows DNA in agarose gel electrophoresis from stem, tendril, root and Figure 3 shows isolated DNA from various flower parts (Rogers et al., 1985). The DNA from Figure 3: F1: (whole flower), 3: F2 (without sepals), 3: F3 (without reproductive system) shows slight degradation, however, DNA from 3: F4 (reproductive system) is pure and intact without degradation.

\section{Annealing temperature $=4(\mathrm{G}+\mathrm{C})+2(\mathrm{~A}+\mathrm{T})$}

At last, PCR cycles affect the amplification of DNA and 30 PCR cycles produces good DNA amplification. Optimization of the RAPD-PCR reaction parameters for amplification of genomic DNA of Passiflora foetida are displayed in Table 3. The PCR reaction was performed in triplicate for reproducibility of amplified 51 fragments, which ranges from (120 bp -2500 bp). Figure 4 shows optimized Akansha RAPD-PCR primers 1-10. The primer no 7 shows highest biased power and 2, 5, 6, 8 show low discriminatory power Williams et al., (1990).

\section{Conclusion}

Thus present protocol denied the use of liquid nitrogen is inexpensive, easy, and less time-consuming effectively yields genomic DNA from the fresh and dry sample. The high level of secondary metabolites from this plant makes extraction difficult. However, optimized protocol flourishing isolates genomic DNA that holds promise for further high-throughput molecular techniques, including AFLP (Segura et al. 2002), RFLP (Botstein et al. 1980), PCR extension and RAPD (Crochemore et al., 2003). Genomic DNA from leaf, tendril, stem, root and flower has been extracted successfully. RAPD analysis can be done prosperously for improvement of fruiting varieties of Passiflora species.

\section{Competing interests}

The authors declare that they have no competing interests.

\section{Authors' contributions}

Dr ASP has planned complete experiment and given valuable suggestion. $\mathrm{BDL}$ has carried out optimization of DNA isolation and RAPD PCR reactions protocol. HMP has helped in manuscript drafting. All authors read and approved the final manuscript.

Received: 14 May 2014 Accepted: 11 August 2014

Published: 23 August 2014

\section{References}

Barra M, Salazar E, Beltrán M, Sagredo B (2012) Simple and robust DNA extraction method for the large-scale analysis of genotypes containing high polyphenolic content, such as landraces of Solanum tuberosum and Zea mays. Plant breeding, genetic and genetic resources. Cien Inv Agr 39(3):593-601

Botstein D, White RL, Skolnick M, Davis RW (1980) Construction of a genetic linkage map in man using restriction fragment length polymorphisms. Am J Hum Genet 32:314-331

Chalmers KJ, Waugh R, Sprent Jl, Simons AJ, Powell W (1992) Detection of Genetic Variation between and Within population of Gliricida sepium and G. maculate using RAPD markers. Heredity 69:465-472

Clark MS (1997) Plant Molecular Biology - A Laboratory Manual. Springer-Verlag Berlin Heidelberg, New York, pp 305-328

Crochemore ML, Molinari HBC, Vieira LGE (2003) Genetic diversity in passion fruit (Passiflora spp.) evaluated by rapid markers. Braz Arch Biol Tech 46(4):521-527

de Andrade Aukar AP, Lemos E g s m, Oliveira JC (2003) Genetic variations among passion fruit species using rapd markers. Revista Brasileira de Fruticultura Jaboticabal - SP 24(3):738-740

Dellaporta SL, Wood J, Hicks JB (1983) A plant DNA minipreparation: Version II. Plant Mol Biol Rep 1:19-21

Dhawan K, Kumar S, Sharma A (2002) Suppression of alcohol cessation oriented hyperanxiety by the benzoflavone moiety of Passiflora incarnata Linneaus in mice. J Ethnopharmacol 8(1-2):239-244

Dhawan K, Dhawan S, Sharma A (2004) J Ethnopharmacol 94:1-23

Doyle JJ, Doyle JL (1987) A rapid DNA leaf material. Phytochem Bull 19:11-15

Doyle JJ, Doyle JL (1990) Isolation of plant DNA from fresh tissue. Focus 12:13-15

Fajardo D, Angel F, Grum M, Tohme J, Lobo M, Roca WM, Sanchez I (1998) Genetic variation analysis of the genus Passiflora L. using RAPD markers. Euphytica 101:341-347

Howland DE, Oliver RP, Davy AJ (1991) A method of extraction of DNA from birch. Plant Mol Biol Rep 9:340-344, http://dx.doi.org/10.1007/BF02672010

Katterman FR, Shattuck VI (1983) An effective method of DNA isolation from the mature leaves of Gossypium species that contain large amounts of phenolic terpenoids and tannins. Prep Biochem 13:347-359

Khanuja SPS, Shasany AK, Darokar MP, Kumar S (1999) Rapid isolation of DNA from dry and fresh samples of plants producing large amounts of secondary metabolites and essential oils. Plant Mol Biol Rep 17:1-7

Kit YS, Chandran S (2010) A Simple, rapid and efficient method of isolating DNA from Chokanan mango (Mangifera indica L). Afr J Biotechnol 9(36):5805-5808

Murray MG, Thompson WF (1980) Rapid isolation of high molecular weight plant DNA. Nucleic Acids Res 8:4321-4325

Puchooa D (2004) A simple rapid and efficient method for Extraction of Genomic DNA from lychee Litchi Chinensis Sonn. Afr J Biotechnol 3(4):253-255

Rogers SO, Bendich AJ (1985) Extraction of DNA from milligram amounts of fresh, herbarium and mummified plant tissues. Plant Mol Biol 5:69-76

Romman S (2011) Comparison of methods for isolating high quality DNA from sage (Salvia officinalis). J Med Plant Res 5(6):938-941 
Segura S, D'Eeckenbrugge GC, Bohorquez A, Ollitrault P, Tohme J (2002) An AFLP diversity study of the genus Passiflora focusing on subgenus Tacsonia. Genet Resour Crop Evol 49:111-123

Souza MM, Santana Pereira TN, Carneiro ieira ML (2008) Cytogenetic Studies in Some Species of Passiflora L. (Passifloraceae): A Review Emphasizing Brazilian Species. Braz Arch Biol Tech 51(2):247-258

Suman PSK, Ajit KS, Darokar MP, Kumar S (1999) Rapid isolation of DNA from dry and fresh samples of plants producing large amounts of secondary metabolites and essential oils. Plant Mol Biol Rep 17:1-7

Ulubelen A, Topcu G, Mabry TJ, Dellamonica G, Chopin J (1982) C-Glycosylflavonoids from Passiflora pittieri, P. alata, P., ambigua and Adenia mannii. J Nat Prod 45:103

Williams JGK, Rubelik AR, Livak KJ, Rafalski JA, Tingey SV (1990) DNA

polymorphisms amplified by artitrary primers are useful as genetic markers. Nucleic Acids Res 18:6531-6535

doi:10.1186/2193-1801-3-457

Cite this article as: Lade et al.: Efficient genomic DNA extraction protocol

from medicinal rich Passiflora foetida containing high level of

polysaccharide and polyphenol. SpringerPlus 2014 3:457.

\section{Submit your manuscript to a SpringerOpen ${ }^{\odot}$ journal and benefit from:}

- Convenient online submission

$\checkmark$ Rigorous peer review

- Immediate publication on acceptance

- Open access: articles freely available online

- High visibility within the field

- Retaining the copyright to your article

Submit your next manuscript at $>$ springeropen.com 